\title{
ECO-ANALYTICAL MONITORING OF RADIOACTIVE MICROELEMENTS AND EVALUATION OF THEIR IMPACT ON DENTAL PERIODONTOLOGICAL STATUS
}

\author{
Maria Stetsyk \\ Senior Lecturer at the Department of Prosthetic Dentistry, \\ Uzhhorod National University, Ukraine \\ e-mail: mariia.stetsyk@uzhnu.edu.ua,orcid.org/0000-0002-4586-5177 \\ Illya Pyrchak \\ Postgraduate Student at the Department of Prosthetic Dentistry, \\ Uzhhorod National University, Ukraine \\ e-mail: illia.pirchak@uzhnu.edu.ua,orcid.org/0000-0002-0719-6793
}

\section{Summary}

The world community has a well-founded concern about anthropogenic pollution and the danger to human health it poses. An important role in increasing the incidence of ecologically polluted areas belongs to the exposure to anthropogenic toxins, certain socio-economic conditions, lifestyle, the presence of bad habits and the nature of human nutrition, and, in particular, the interaction of these risk factors. The effect of various endogenous factors in modern socio-ecological conditions on the human body is diagnostically manifested in the form of functional shifts in the parameters of oral fluid, which are mainly adaptive-compensatory in nature. The microelement composition of biological fluids reflects the total amount of toxic substances received from the environment, which is why it is an indicator of the impact anthropogenic pollution and can be a test object in the ecological and analytical monitoring of micronutrients. The level of macro- and micronutrients and the immunoglobulin status of the altered picture reflects the state of the oral cavity local immunity, internal organs and the human environment, because the indicator, reflecting the physical status, can use the signaling system in pathological homeostasis. The most common cause of decreased body resistance is adverse long-term exogenous factors that have a pronounced effect on both the immune system and the local immunity of the oral cavity, and the trace element composition of mixed saliva can be regarded as parameters of local resistance of the oral cavity.

Keywords: odontostatus, diseases of the periodontal complex, oral fluid, essential chemical elements, immune homeostasis, radiation-contaminated area, osteotropic radio pollutants.

DOI https://doi.org/10.23856/4337

\section{Introduction}

The world community has a well-founded concern about anthropogenic pollution and the danger to human health it poses.

Pathological changes in the human body that occur due to shifts in ecological homeostasis are considered as eco-conditioned pathology (Zerbino D.D., 2009: 208; Horishyna O.V., 2006: 60; Hruzieva O.V., 2007: 167-168).

When the morpho-functional capabilities of the organism are depleted, a deep critical state arises, which is manifested by a non-specific endogenous intoxication syndrome, which is 
characterized by a number of differences depending on the etiological nature and severity of the underlying disease (Vasilenko I.Ya., 2006: 4-5).

An important role in increasing the incidence of ecologically polluted areas belongs to the exposure to anthropogenic toxins, certain socio-economic conditions, lifestyle, the presence of bad habits and the nature of human nutrition, and, in particular, the interaction of these risk factors (Dobrovolskyi L.A., 2008: 25-29; Gzhegockij M.R., 2002: 575-596; Hruzieva T.S., 2010: 167-168; Yahenskyi A.V., 2007: 64-67; Vasilenko I.Ya., 2006: 4-5).

\section{Topicality}

The ability to detect the content of radioactive trace elements in unstimulated mixed saliva as an indicator of the impact of anthropogenic pollution, with subsequent characterization and assessment of the antioxidant and immune systems (local oral immunity) is a topical issue today. After all, the effect of high concentrations of pollutants is accompanied by their accumulation in the relevant tissues and organs of the human body. The microelement composition of biological fluids reflects the total amount of toxic substances obtained from the environment (air, water, soil) and food.

\section{The aim of study}

To study the microelement composition of saliva in patients living permanently in radiation-contaminated areas, patients with chronic generalized periodontitis of varying severity.

\section{Research goals}

1. To determine the quantitative and qualitative biochemical parameters and properties of oral fluid in persons who permanently live in conditions of radiation exposure.

2. To conduct a comparative analysis of changes in dental and periodontal status in the studied populations.

3. To establish the relationship between the development and progression of periodontal disease and general somatic pathology in persons living permanently in radiation-contaminated areas.

4. To substantiate the expediency and clinical effectiveness of optimization of periodontal treatment protocols and methods of dental status registration patients which are resident in radiation-contaminated areas, taking into account the specifics of ionizing-associated pathological changes of the dental-maxillary apparatus.

\section{Materials and Methods}

The subjects were patients with chronic generalized periodontitis of varying severity, which according to certain criteria were divided into the following groups of clinical trials.

The main group of the study consisted of 46 people living in the radiation-contaminated area - with. Children, Ivankiv district, Kyiv region. (30 km exclusion zone after the accident at the Chernobyl nuclear power plant (ChNPP)).

The comparison group was presented by 38 patients from Kyiv as a settlement with the most developed urban system and the highest level of man-caused load. 
The control group consisted of 22 healthy individuals with clinically healthy gum tissue in intact and reduced periodontium, ie non-periodontal patients or «stabilized» periodontal patients.

The subject of biochemical studies was the oral fluid of patients with chronic generalized periodontitis of varying severity (CKD).

For the purpose of salivary diagnostics we carried out definition of speed of salivation, measurement of $\mathrm{pH}$ of oral and gingival liquids.

To determine the rate of salivation, oral fluid was collected in graduated tubes, in the morning, on an empty stomach, before oral hygiene, without stimulation for 10 minutes, after rinsing the mouth with distilled water, followed by calculation according to the appropriate formula.

A capillary hemoviscosimeter «VK-4» («Transmetal LLC», Russia) was used to determine the viscosity of the oral fluid. The unit of viscosity was taken as centipoise (SP).

The acid-base state in the oral cavity was assessed using the most informative hydrogen index $(\mathrm{pH})$. Determination of the $\mathrm{pH}$ of the oral fluid was performed with a laboratory test system «Saliva Check Buffer» («GC», Japan). The test strips were immersed in a container with oral fluid for 10 seconds, and then compared the color of the test strips with the table from the kit.

The $\mathrm{pH}$ of the oral fluid was determined in relative units using a digital $\mathrm{pH}$ meter («Radelkis», Hungary) immediately after its collection.

To determine the gingival fluid $\mathrm{pH}$ the excretory ducts of the large salivary glands were isolated with cotton balls, the surface of the teeth and gums in the study area was dried, then the test strips from the Saliva Check Buffer set were immersed in the gingival cleft or periodontal pocket for 10-15 seconds. Then compared the color of the test strips with the table from the kit.

The microelement composition of oral fluid ( $\mathrm{Fe}, \mathrm{Zn}, \mathrm{Mn}, \mathrm{Cu}, \mathrm{Cr}, \mathrm{Pl}, \mathrm{Sr}$, etc.) was determined by the spectral method using the atomic absorption spectrophotometer C-115 PC (Ukraine). Determination of the content of macronutrients was performed using a biochemical analyzer «Humalyzer 2000».

In order to determine the immune homeostasis of the oral cavity in patients with chronic generalized periodontitis, a study of the titer of secretory immunoglobulin A ( $\operatorname{sgA})$ in the oral fluid at 3, 6, 12 months of treatment. Its level was determined by the method of solid-phase enzyme-linked immunosorbent assay (ELISA), using tablets manufactured by «Vektor-Best» and a universal photometer («Absorbance Microplate Reader» Elx800, BioTek). The analysis was performed in two stages. In the study of samples during the first incubation, sIgA binding occurs. During the second incubation, the conjugate of monoclonal antibodies to $\alpha$ chains of horseradish peroxidase IgA binds to sIgA immobilized during the first incubation. Immobilized monoclonal antibodies «sIgA-conjugate» are formed, which are detected by color reaction using a peroxidase substrate: hydrogen peroxide and tetramethylbenzidine chromogen. The color intensity is proportional to the concentration of sIgA in the analyzed sample. After measuring the optical density of the solution in the wells on the basis of the calibration graph was determined by the concentration of $\operatorname{sgA}$ in the test samples according to the classical variant according to the instructions. The sensitivity of the method is $0.35 \mathrm{pg} / 1$.

\section{Main content}

\section{Oral fluid as a test system}

Oral fluid is an integral part of the fluid environment of the human body, in its composition it is a complex biological substrate, which consists of the secretion of salivary glands, 
polymorphonuclear leukocytes (PYAL), desquamated epitheliocytes, food detritus and oral microbiota. In recent years, scientific studies have obtained data that confirm the clinical and diagnostic parallelism of differentiation and changes in the parameters of peripheral blood and oral fluid in a number of general somatic diseases (Gilmiyarova F.N., 2006: 312). That is why the analysis of mixed saliva is a valuable alternative informative non-invasive diagnostic method in cases where blood sampling is impossible for one reason or another (Vavilova T.P., 2008: 22-25).

The effect of various endogenous factors in modern socio-ecological conditions on the human body is diagnostically manifested in the form of functional shifts in the parameters of oral fluid, which are mainly adaptive-compensatory in nature.

The composition and properties of saliva are influenced by a number of individual parameters: general somatic condition of the body, functional activity of salivary glands, saliva viscosity, oral hygiene, consistency of food and the presence of food residues on the tooth surface, depending on the initial dental status of the patient.

The acid-base balance of the oral cavity is characterized and interrelated with the rate of salivation, the interaction of salivary buffer systems (bicarbonate, phosphate and protein systems), metabolites of the oral biofilm and the dental status of the patient.

The values of $\mathrm{pH}$ in the normal state are in the range of 6.5-7.5.

The set of buffer systems forms the first line of protection of teeth and periodontal tissue from acidic and alkaline influences (phosphate c-mobile is active at $\mathrm{pH}=6.8-7.0$, bicarbonate at $=6.1-6.3$, protein provides a buffer) capacity at what are the $\mathrm{pH}$ values).

Update of acid-base intelligence after the «attack» in the normal state extends to the chemical indication, and in case of unsatisfactory operation of the buffer systems will be underestimated. This pattern is accompanied by an improvement in the rate of demineralization of the enamel, initiating the development of carious and non-carious lesions of the hard tissues of the teeth.

\section{"Macro" role of essential trace elements}

The level of macro- and microelements and immunoglobulin status of mixed saliva reflects the state of local immunity of the oral cavity, internal organs and environments of the human body, so it is a kind of marker that reflects the physiological status of the body and can serve as a signaling system for pathological homeostasis.

Trace elements are components of substances that participate in the metabolic and regulatory processes of the human body.

Particular attention is drawn to the content in mixed saliva of the following trace elements - lead, strontium, cadmium, nickel, cobalt, manganese and aluminum, because these metals are osteotropic, and therefore compete with calcium on the formation of apatite hard tissues of teeth and periodontal bone; replacing calcium during the processes of mineralization, demineralization and remineralization (Ibragimova M.Ya., 2011: 606-609; Skalnyj A.V., 2004: 272).

It is important to note that trace elements also act as anti- and prooxidants, which ensures the formation and maintenance of balance in the system of «generation-detoxification» of free radicals (Skalnyj A.V., 2004: 216).

To assess the level of antioxidant protection, it is important to analyze the content of the following trace elements in mixed saliva - calcium, magnesium, selenium, zinc, copper and iron, as they are cofactors of enzymes and reducing their concentration automatically leads to reduced enzyme activity.

The content of the following trace elements in the human body are particulary important - copper, selenium, magnesium and zinc, as through the regulatory mechanisms of immunogenesis they act on protein synthesis, energy processes in the cell and regulate the immune 
response at both cellular and humoral levels. Deficiency of the above trace elements increases the sensitivity to the penetration of infectious agents, reduces the production of interleukin-II and interferon-g, inhibits the lytic activity of natural killers and their relative content in the population of T-lymphocytes.

\section{Analysis of the obtained results}

living in radiation-contaminated areas indicators of the prevalence and intensity of the carious process does not differ significantly from similar indicators in the surveyed control and comparison groups. This can be explained by the patients 'less attention to their own health, their lack of routine dental examinations and oral remediation, and the long period of time that has elapsed since the Chernobyl accident. However, the prevalence of non-carious lesions of hard tissues of teeth of dystrophic nature (pathological abrasion, wedge-shaped defects, erosions and abrasion of enamel), diseases of the oral mucosa and periodontal complex, the presence of dentition defects in the main and comparative groups is higher than in the control group. Chronic generalized periodontitis in the main study group, in contrast to the periodontitis of men in the comparative group, was characterized by a more severe areactive course of the disease, indicating the adverse effects of long-term action of radioactive elements accumulated in periodontal bone.

As a result of studies of the level of concentration of trace elements in mixed saliva in patients of the main and comparative groups, the content of metals that are competitors of calcium is much higher than in the control group. Content of lead in 3.5 times, manganese -3 times, strontium - 12 times, cadmium 29 times, chromium 4 times, cobalt and aluminum 5 times.

The content in saliva of essential trace elements that act as anti- and prooxidants, which are cofactors of enzymes - zinc, copper, selenium, magnesium, iron and calcium is much lower than in the control groups: calcium and copper in 2 times, magnesium in 1,5 times, iron 6 times, zinc 6.5 times. During the analysis of the microelement composition of tartar, $50 \%$ of calcium, up to $30 \%$ of inorganic phosphorus and $0.7 \%$ of magnesium are determined, traces of lead, strontium, silicon, molybdenum, aluminum, cadmium and fluorine are traced as a residue. As the degree of environmental tension increases, the content of the following elements in mixed saliva decreases - zinc, selenium, copper and magnesium, which play an important role in the regulation of the immune response.

\section{Conclusions}

The results above indicate the possibility of using mixed saliva as a test object in the ecological and analytical monitoring of essential trace elements, such as zinc, copper, selenium, iron and calcium, which are part of many enzymatic systems of the body, chromium, lead, Nickel, cadmium, cobalt, manganese, strontium and aluminum are toxic metals, their high content can lead to an imbalance of one of the most important homeostatic systems of the body - the immune system, which determines the degree of general health and its adaptive capacity which is the primary link in the chain of biological response to xenobiotics. Given the fact that the most common cause of decreased body resistance are adverse long-term exogenous factors that have a pronounced effect on both the immune system and the local immunity of the oral cavity, and indicators of micronutrient composition of mixed saliva can be regarded as parameters of local resistance of the oral cavity. One of the mechanisms by which the influence of environmental factors on the human body is realized is «oxidative stress». 
The obtained results can serve as a basis for further widespread use of salivary diagnostics in diagnostic medicine, as the development of parameters will confirm the permeability of the blood-salivary barrier, which will open new opportunities in the diagnosis and treatment of dental diseases.

\section{References}

Dobrovolskyi L.A., Belnysova Y.H. (2008). Teoretycheskye y metodolohycheskye aspekty sviazy mezhdu zahriaznenyem vozdukha y sotsyalno-ekonomycheskymy faktoramy v kontekste zdorovia naselenyia [Theoretical and methodological aspects of the relationship between air pollution and socio-economic factors in the context of health]. Dovkillia ta zdorovia [in Russian] Gilmiyarova F.N., Radomskaya V.M., Ryskina E.A. (2006) Analiticheskie podhody k izucheniyu pokazatelej metabolizma $v$ rotovoj zhidkosti [analytical approaches to the study of indicators of metabolism in the oral fluid]. Moskow: Kniga [in Russian]

Gzhegockij M.R., Shtabskij B.M. (2002) Ksenobiotiki v okruzhayushej srede: fiziko-toksikologicheskie osnovy sistemnogo podhoda k obosnovaniyu normativov himicheskoj bezopasnosti cheloveka (obzor literatury i sobstvennyh issledovanij) [Xenobiotics in the environment: physical and toxicological foundations of a systematic approach to the substantiation of standards for human chemical safety]. Zhurnal AMN Ukrayini [in Russian]

Horishyna O.V. (2006) Chornobyl zalyshaietsia z namy. Chornobylska katastrofa ta stan zdorovia naselennia [Chernobyl remains with us. The Chernobyl disaster and the state of health of the population]. Kyiv: Pidsumky naukovykh doslidzhen [in Ukrainian]

Hruzieva T.S. (2010) Vplyv ekolohichnykh chynnykiv na formuvannia hlobalnoho tiaharia khvorob [The influence of environmental factors on the formation of the global burden of disease]. Kyiv: Naukovyi visnyk NMU im. O.O. Bohomoltsia [in Ukrainian]

Hruzieva O.V. (2007) Problemy zdorovia naselennia, poviazani z ekolohichnymy chynnykamy [Population health problems related to environmental factors] Kyiv: Naukovyi visnyk NMU im. O.O. Bohomoltsia [in Ukrainian]

Ibragimova M.Ya. (2011) Vzaimosvyaz disbalansa makro- i mikroelementov i zdorove naseleniya (obzor literatury) [The relationship between the imbalance of macro- and microelements and the health of the population]. Kazanskij medicinskij zhurnal [in Russian]

Skalnyj A.V., Rudakov I.A. (2004) Bioelementy v medicine [Bioelements in medicine]. Moskow: Izdatelskij dom «Oniks 21 vek»: Mir [in Russian]

Skalnyj A.V. (2004) Himicheskie elementy v fiziologii i ekologii cheloveka [Chemical elements in human physiology and ecology] Moskow: Mir [in Russian]

Yahenskyi A.V., Sichkaruk I.M. (2007) Otsinka yakosti zhyttia u suchasnii medychnii praktytsi [Assessment of quality of life in modern medical practice] Kyiv:Vnutrishnia medytsyna [in Ukrainian]

Vasilenko I.Ya., Vasilenko O.I. (2006) Medicinskie problemy tehnogennogo zagryazneniya okruzhayushej sredy [Medical problems of technogenic pollution of the environment]. Moscow: Medicina truda i prom. ekologiya [in Russian]

Vavilova T.P. (2008) Biohimiya tkanej i zhidkostej polosti rta [Biochemistry of tissues and fluids of the oral cavity]. Moscow: GEOTAR-Media [in Russian]

Zerbino D.D. (2009) Ekolohichni khvoroby: postanovka problem [Environmental diseases: problem statement]. Kyiv: Mystetstvo likuvannia [in Ukrainian] 